\title{
Konservatuvar Eğitimine Sosyolojik Bir Bakış
}

DOI NO: $10.5578 / J S S .6967$

Uğur Türkmen ${ }^{1}$

\begin{abstract}
Özet
Ülkemizde farklı konservatuvar adları ve bu konservatuvarlarda farklı bölüm, anabilim dalı ve Ana sanat dall yapllanmalarl vardır. Bu farklılıklar programlara da yansımış eğitim ögretim faaliyetleri birbirinden kopuk bir hal almıştır. Bir program tam olarak gelişimini tamamlamadan yeni program ve programlar açılmış ve yeni sorunların çıkmasına yol açmıştır. Şu anki mevcut durum da konservatuvar mezunlarının hangi unvanı alacă̆ı bile tartışma konusudur. Dört yıl lisans eğitimi alan bir mezun "sanatçı" unvanı ile tanımlanabilecek midir? Bu çalışma; akademik alt yapıların yeterliliği veya yetersizliği, mezunların istihdam sorunları vb daha birçok konu ve problemin kaynağının konservatuvar yapılanmalarından kaynaklandığı düşüncesinden yola çıkılarak hazırlanmıştır. Sosyolojik bir bakış açısıyla ele alınan çalışmada; ülkemizde ki mevcut durum incelenmiş, yapılandırılmış görüşme formu hazırlanmış ve mevcut durum hakkında konservatuvar eğitimcilerinden görüş alınmıştır. Veriler nitel çözümleme tekniklerine göre analiz edilmiş ve yorumlanmıştır. Çalışmanın ülkemizdeki konservatuvar yapılanmalarındaki sorunlara dikkat çekmesi bakımından önemli olduğu düşünülmektedir.
\end{abstract}

Anahtar kelimeler: Konservatuvar, yapılanma, olgusal yaklaşım

\section{A Sociological View onto Conservatory Training}

\begin{abstract}
There are different conservatories' names and the different departments, divisions and branch structures of Arts. These differences are reflected in the education and teaching activities programs and made them detached from each other. New programs and activities have been opened without completing old one sand this situation led to new problems. The existing situation is - which title will be taken by conservatory graduates under debate too. Can a four-year bachelor's degree graduate be defined as "artist"? This study's idea was prepared due to sufficiency or insufficiency in the infrastructures, graduates' employability problems and much more subjects, the problems of the conservatory' structuring etc. Prepared on the basis of the sociological view; the current situation in our country was analyzed, structured questionnaire was prepared and conservatory's educators
\end{abstract}

1 Doç.Dr., Afyon Kocatepe Üniversitesi, Devlet Konservatuvarı Fakültesi, Müzik Bölümü. uturkmen@aku.edu.tr 
were interviewed about the current situation. According to the qualitative data analysis techniques have been analyzed and interpreted. This study thought to be important in terms of structures to attract attention to the problems in the conservatory of our country.

Keywords: Conservatory, structuring, factual approach

\section{Giriş}

Sanatç1-sanat eğitimcisi- araştırmac1 ve besteci yetiştiren konservatuvarlar içinde bulunduğu ilin, bölgenin, ülkenin sosyo kültürel değişimine katkıda bulunurlar.

Konservatuvarlar; kuruldukları günden bugüne sanatı meslek olarak seçen bireylerin yetişmesini sağlamış, istihdam yaratmış, ülke ve dünya kültürüne hizmet etmişlerdir.

Bununla birlikte dün olduğu gibi bugünde konservatuvar eğitimi sorgulanmaktadır. Genel ve özel amaçlarının yerine gelip gelmediği, doğru öğrencilerin yetişip yetişmediği, dünya gidişatına yönelik kurumsal yapılarında değişimlerin olup olmadığına yönelik sorgulamalar her geçen gün artmaktadır. Örneğin konservatuvarlar sadece profesyonel müzik eğitimiyle mi ilgilemelidirler? Genel müzik eğitiminin sorunlarına yönelik çalışmaların neresindedirler? Amatör müzik eğitimi kendi eğitim sistemleri içerisinde hiç mi yer almayacaktır? vb sorular farklı ortamlarda dile getirilmektedir.

Elbette her kurumun özel ve genel amaçları olacaktır. Konservatuvarlarında en özel ve nihai amac1, sahne sanatları temelli "icrac1besteci-araştırmacı ve icra ağırlıklı eğitimci” yetiştirmektir. Bununla birlikte icra-araștırma-besteleme boyutlarına katılan konservatuvar eğitimci ve yöneticileri iş "eğitimci de yetiştirmelisiniz" düşüncesine gelince duraksamakta ve önyargiyla bakmaktadırlar. Sorun basittir. Konservatuvarlarda eğitim verecek eğitmenler kimler tarafindan ve nasıl yetiştirilecektir?

Konservatuvar eğitiminden beklenenler tıpkı Peanuts çizgi dizisinde konu edildiği gibi mi olmalıdır? 
Resim. 1

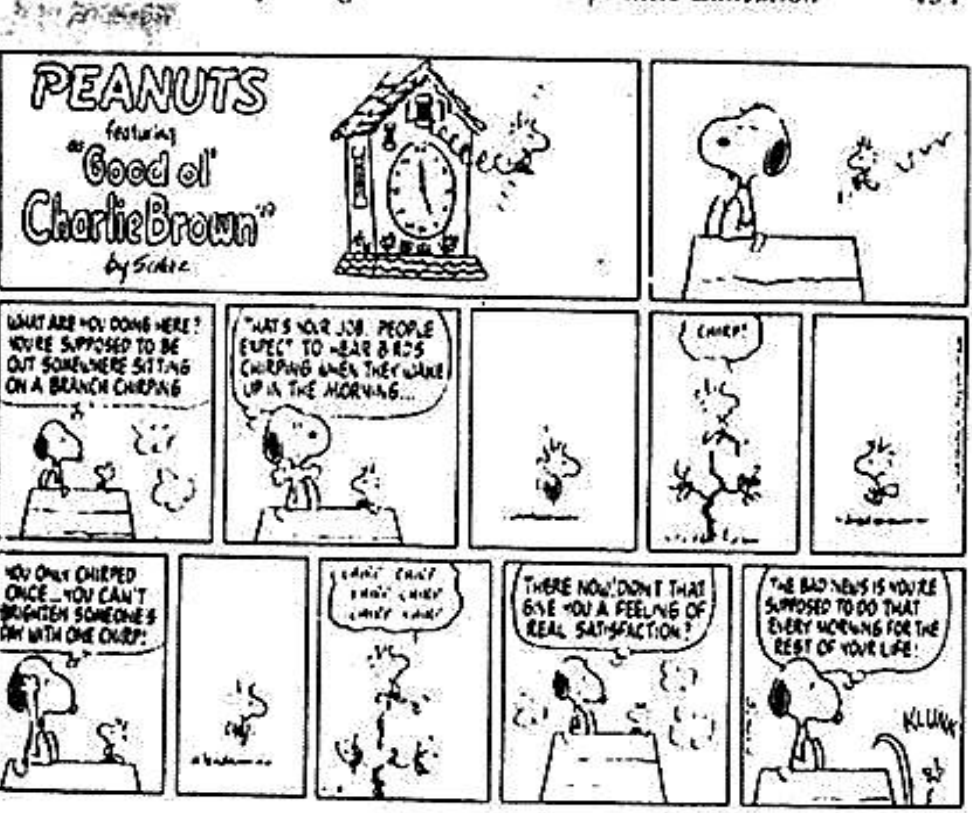

Figure 6.I. PEANUTS reprinted by permission of UFS, Inc.

-Burda ne işin var. Senden bir dalda oturman ve ötmen bekleniyor

-Bu senin işin. İnsanlar sabahları kalktıklarında kuşların ötüşünü duymayı beklerler

-Cirp(cik)

-Sen sadece bir kez öttün. Sen bu ötüşle birinin gününü aydınlatamazsın

-Cik-Cik-Cik-Cik-Cik-Cik-

-İşte oldu. Bu sana gerçek hoşnutluk hissi vermedi mi?

-Kötü tarafı şu ki hayatının sonuna kadar bunu her sabah yapman gerekir. (Abeles;1994;151)

Konservatuvar eğitimcileri ve yöneticilerinden, zavallı kuş’un kaderi gibi hep aynı şey mi istenmektedir?

Sanırız cevabı evettir.

Çalacaksın ve söyleyeceksin. 
Karikatürde vurgulandığı gibi konservatuvar eğitimcilerinin ve yöneticilerinin beklentilere cevap verebilmeleri önemlidir. Konservatuvarlılara biçilen roller vardır. "Roller belli bir sosyal sistemin ürünü olarak o ortamda doğarlar. İnsan davranışlarının rollere uygun olarak gelişmesini etkilerler. Ayrıca roller, toplum değerleri ile de etkileşirler, yeni değerlerin oluşmasına neden olabilirler" (Günay,2006;171). Bununla birlikte bireylerin ve içinde yaşanılan toplumun beklentilerinin üzerinde, farkındalık yaratan, üreten, sergileyen, değişim ve gelişime katkıda bulunan profesyonel müzikçilere daha çok ihtiyaç duyulmaktadır. "Müziğin amacı; bestecinin özgür seçimine göre biçimlenmiştir. Aynı besteci, kendi bireysel duygularını ve düşüncelerini bir sanat yaratısına dönüştürme çabasında bulunabildiği gibi, kendisi içinde bulunduğu ya da etkilendiği toplumun bir gözlemcisi olarak etkilendiği, sorumluluk duyduğu konular varsa onları yaratısına yansitabilir" (Günay, 2006; 118-119)

Konservatuvarlarda icracılıkta en üst noktaya ulaşmak en önemli hedeftir. Bununla birlikte solistlik hedefi sürecinde bazı gerçeklikler göz ardı edilebilmektedir. Örneğin oda müziği derslerinin üzerinde yeterince durulmadığ1 bilinmektedir. Bu konuda Ünalp (2013;30-33) müzisyenlerle 'ülkemizde oda müziği kültürünün neresindeyiz?' adlı söyleşisinde müzisyenlerden şu bilgileri edinmiştir. Hakan Şensoy "Eğitim aldı̆̆ım kurumda bir oda müziği geleneğinin olmaması, bu konuda eksik kalmamızın en önemli nedeni olmuştur" derken, Murat Berk okulda kendilerini bu konuda pek teşvik edenin olmadığını belirtir. Özcan Ulucan ise durumun Bulgaristan da önemsendiğini ama teşvik edilmediğini belirtir. Cihat Așkın'da "maalesef eğitimim sırasında böyle bir teşvik görmedim” der ve gönüllü olarak oda müziği yaptığını söyler. Çetin Aydar ise sorunun genelde olduğunu belirtir. "Hiç oda müziği yapmadan mezun olan arkadaşlarımız da vard1. Şu an bir eğitimci olarak bu konuya öğrencilerin ve eğitim kurumlarının daha fazla eğildiğini biliyor ve gözlemliyorum" diyerek geçmişe göre bir düzelmenin olduğunu vurgular. Bülent Oral'da konservatuvar öğrencilerinin yetiştirilme tarzlarında ki duruma dikkat çeker. "Konservatuvarlarda öğrenciler solist gibi yetiştiriliyor, bu yüzden oda müziği derslerine gereken önem verilmiyor. Öğrenciler mezun olup orkestralara girdikleri zaman beraber çalmakta zorlanıyorlar. Özellikle bir opera orkestrasına girmişseniz bu daha da zor oluyor. Oda müziği dersleri ciddiye alınmalı ve artırılmalı"

Aynı şekilde genel müzik eğitiminin sorunlarının doğrudan profesyonel müzik eğitimini etkilediği gerçeği konservatuvar çalışanları tarafından göz ard1 edilmektedir. Örneğin Afyon Kocatepe Üniversitesi Devlet Konservatuvarı'nda görevli bir grup eğitimci tarafından düzenlenen “Müzik Eğitimcileri Çalıştayı"na yine aynı kurumdan eğitimciler karşı çıkmışlar ve profesyonel müzik eğitimi yapılan bir kurumda müzik öğretmenlerine yer 
olmadığı, bu çalışmaların Eğitim Fakültelerince yapılması gerektiğini belirtmişlerdir. Maalesef; müziği seven, konservatuvar eğitimini seven, çalışma ortamı müzik eğitimine müsait, mesleki motivasyonu yükseklerde olan müzik öğretmeni ve sinıf öğretmenlerinin profesyonel müzik eğitimine alt yap1 hazırlayacağı, öğrencilerini yüreklendireceği gerçeği göz ard1 edilmektedir.

Konservatuvar eğitiminde bir diğer göz ardı edilen kesim ise amatör müzikçilerdir. Dünyanın birçok ülkesinde birçok sanatçı ve pedagog amatör müzik eğitimi ile ilgilenmiş ve çalışmalara destek olmuştur. Kodaly, Dalcrose, Orff, Suziki'nin doğrudan profesyonel müzik eğitimini hedeflememiş, müziği, çalgı eğitiminin, ses ve koro eğitiminin genele yayılması, ulaşılabilen herkese ulaşılması gerektiğini savunmuşlardır. Ülkemizde de Mithat Fenmen bu konuda ciddi olarak söylemlerde bulunmuştur. Ona göre Amatör müzik eğitimi profesyonel müzik eğitimini destekleyen en önemli damarlardan biridir. Yine ülkemizde keman sanatçısı Cihat Așkın tarafından kurulan ve bugün yedi șubeye ulaşanCAKA (Cihat Aşkın ve Küçük Arkadaşları) keman eğitim felsefesi, amatörlere eğilmiştir Așkın'a göre sistem bir priamit'i andırmaktadır. Bu sistem içerisinden mesleği müzik olarak seçen sanatçılar, sanat eğitimcileri, hayatında kemana sürekli yer veren amatör müzikçiler çıkacaktır. (görüşme 3 Mart, 2013)

Konservatuvar eğitiminde belkide en önemli sorunlardan birine Usmanbaş (1988:13) şu şekilde değinir: Ülkemizde profesyonel müzikçinin eğitimi, dünya standartlarının altındadır. Araç, gereç, kitap, nota, çalg1 noksandır. Bu alanda başvurular azdır. Amaçsız bir yetiştirme yapılmaktadır. Dünyaya kapalı çevrede iletişim eksiklikleri yaşanmaktadır. Gençler arasında yarışma ruhunun yokluğu vardır.

Profesyonel müzik eğitimi veren konservatuvarların; amatör ve genel müzik eğitimine eğilmesi gerektiği yanında "sosyal pedagog" yetiştirmeleri gerektiği düşüncesi de araştırmacı tarafından uzun bir süredir dile getirilmektedir. Alman bilim adamı Adolf Diesterweg(1790-1866) tarafindan ilk defa ortaya atılan bu terim, toplumda mağdur duruma düşmüş, sosyal yönden tecrit edilmiş veya şahsî yönden problemleri olan insanların sosyal hayata yeniden kazandırılmaları, bağımsız ve üretken hâle gelmelerini sağlayan terapoytik, eğitimsel ve danışmaya yönelik hizmetlerin bütünüdür. Daha basit bir yaklaşımla sosyal pedagoji, sosyal sorunlu çocuk, genç ve yetişkinlerin okul dışı eğitim ve terbiyesidir. (www.sosyalpedagog.com).

Yaş, cinsiyet ayrımı gözetmeksizin; özürlüler, psiko-sosyal sorunları olanlar, vb hemen her alanda konservatuvar eğitimi hedefleri içerisine alınabilecek birçok çalışma alanı mevcuttur. Bugün özellikle Amerika'da ki birçok müzik kurumu yaşama boyu eğitim felsefesinden yola çıkarak yaş fark1 gözetmeksizin müziğe meraklı her bireye eğitim vermektedir. Ülkemizde ise sadece ilgi alanımla çalışırım düşüncesi hâkimdir. Günümüz 
eğitim anlayışında bireyi okul sınırları içinde değil, onun yaşamı boyunca sürekli eğitilmesi gerekliliği üzerinde durur. Birçok üniversitede "'Yaşam Boyu Eğitim Merkezleri”nin kurulmasındaki ana amaçlardan biri de budur.Toplumun kültürel mirasının gelecek kuşaklara aktarılması, bireyin toplumsallaşması, sistem için gerekli olan elemanların yetiştirilmesi, (devletten devlete değişmekle birlikte) devlet için gerekli olan siyasal bilinci verilmesi amaçlanmıştır. Sosyal pedagoji toplumsal eğitim bilimidir. Toplumda mağdur duruma düşmüş, sosyal yönden tecrit edilmiş veya şahsi yönden problemleri olan insanların sosyal hayata yeniden kazandırılmaları, bağımsız ve üretken hale gelmelerini sağlayan eğitimsel ve danışmaya yönelik hizmetlerin bütünüdür. Daha basit bir anlatımla sosyal pedagoji, sosyal sorunlu çocuk, genç ve yetişkinlerin okul dişı eğitimidir. Sosyal pedagog ise, bu eğitimi uygulayan ve uygulamalar eşlik eden pedagojik ve psikolojik teorilere profesyonel açıklık getirmeye çalışan uzman kişidir. (http://hanimdemirbas.com.tr/pedagoji.php)

Bir diğer sorun konservatuvarların kültür endüstrisi ilişkileridir.

Konservatuvar ailesi, çalışanları, öğrencileri, yöneticileri sanat ve sanat eseri peşinde mi koşacaklar yoksa endüstrinin bir unsuru olarak mı eğitim öğretim faaliyetlerine devam edecekler? Say "Eğitim sonuçlarıyla ölçüler" demekte, konservatuvarların iş alanına dikkat çekmekte ve şu soruyu sormaktadır. "Konservatuvarlarda profesyonel müzikçi olarak yetiştirdiğimiz gençlerimiz, okulu bitirdikten sonra, birey olarak kendileri için, yakın çevresi olan aileleri için, toplumumuz için ve insanlık için yararlı olacak bir sürece giriyorlar mı" $(2007 ; 13)$

Endüstri ürünü; birbirinin tıpkıs1-aynıs1 ürünlerin çoğaltılmas1, tüketilmesinden ibarettir. Önüne geçilemez bir güç karşısında konservatuvarların tutum ve davranışları nasıl olmalı? Elbette bu ve benzeri soru ve sorunların cevabı tek değil. Bununla birlikte konservatuvarlar, kültür endüstrisinin içerisinde yaşayarak kendine bir yol çizebilmelidir.

\section{Ülkemizde Konservatuvarlar}

Bugün ülkemizde konservatuvarların sayısı 35 'i bulmuştur. Kesin olarak bilinememektedir çünkü kâğıt üzerinde açılan ama öğrenci alamayan konservatuvarların olduğu bilinmektedir. Yine bugün itibariyle beş farklı adlandırma altında eğitim verilen konservatuvarlarda en önemli eksikliğin felsefe'lerinin olmadığıdır düşüncesi konunun ilgililerince açıça dile getirilmektedir.

Aşağıdaki tabloya bakıldığında felsefe eksikliğinin yapılanmalara ne derece yansıdığı görülecektir. Beş farklı konservatuvar adı vardır. Aynı işi yapan ama farklı adlandırmaları olan bölüm ve Anasanat dalı adlandırmaları vardır. Aynı işi yapan ama hem bölüm hem Anasanat dalı olarak adlandırılan 
yapılanmalar vardır. Türk müziği eğitiminin bütünlük içinde alan ama bunun yanında ayıran yapılanmalar vardır. Ortaokul ve lisesi olan ve de olmayan konservatuvarlar vardır ve hepsi sanatçı yetiştirdiğini iddia etmektedir. $\mathrm{Bu}$ ve benzeri tespitler çoğaltılabilir.

Tablo1. Günümüz Konservatuvar Yapılanmaları

\begin{tabular}{|c|c|c|c|}
\hline $\begin{array}{l}\text { KONSERVATUVAR } \\
\text { ADI }\end{array}$ & BÖLÜM ADI & ANASANAT DALI ADI & ANABİLIM DALI ADI \\
\hline $\begin{array}{l}\text { *Devlet Konservatuvar1 } \\
\text { *Devlet Türk Musikisi } \\
\text { Konservatuvar1 } \\
\text { *Konservatuar } \\
\text { *Türk Musikisi Devlet } \\
\text { Konservatuvarı } \\
\text { *Türk Müziği Devlet } \\
\text { Konservatuvar1 }\end{array}$ & $\begin{array}{l}\text { *Bestecilik } \\
\text { *Çalgı } \\
\text { *Çalgı Eğitimi } \\
\text { *Çalgı Yapım } \\
\text { *Geleneksel Türk } \\
\text { Müziği } \\
\text { *Komposizyon } \\
\text { *Müzik } \\
\text { *Müzik } \\
\text { Teknolojileri } \\
\text { *Müzik Teorisi } \\
\text { *Müzikoloji } \\
\text { *Opera ve Konser } \\
\text { Şarkıcıllğ̆1 } \\
\text { *Sahne Sanatları } \\
\text { *Ses Eğitimi } \\
\text { *Temel Bilimler } \\
\text { *Tiyatro } \\
\text { *Türk Halk Müziği } \\
\text { *Türk Halk } \\
\text { Oyunları } \\
\text { *Türk Musikisi } \\
\text { *Türk Müziği } \\
\text { *Türk Sanat Müziği }\end{array}$ & $\begin{array}{l}\text { *Bale } \\
\text { *Bestecilik (Kompozisyon) } \\
\text { *Caz } \\
\text { *Çalgı } \\
\text { *Çalgı Eğitimi } \\
\text { *Etnomüzikoloji ve Folklor, } \\
\text { *Geleneksel Türk Halk Müziği } \\
\text { *Geleneksel Türk Sanat Müziği } \\
\text { *Geleneksel ve Modal Müzikler } \\
\text { *Genel Müzikoloji, } \\
\text { *Klasik Gitar } \\
\text { *Klasik Türk Müziği } \\
\text { *Kompozisyon } \\
\text { *Kompozisyon ve Müzik Teorisi } \\
\text { *Kompozisyon ve Orkestra Şefliği } \\
\text { *Koro } \\
\text { *Modern Dans } \\
\text { *Nefesli Çalgıllar Vurmalı Çalgılar } \\
\text { *Nefesli Sazlar } \\
\text { *Opera } \\
\text { *Opera ve Koro Şarkıcılı̆̆ı } \\
\text { *Opera-Koro } \\
\text { *Opera-Şan } \\
\text { *Opera-Tiyatro } \\
\text { *Orkestra ve Koro Şefliği } \\
\text { *Oyunculuk } \\
\text { *Piyano } \\
\text { *Piyano-Gitar } \\
\text { *Piyano-Gitar-Arp } \\
\text { *Popüler Müzik Şarkıcıllı̆ı } \\
\text { *Ses } \\
\text { *Ses Eğitimi } \\
\text { *Şan } \\
\text { *Şan- Opera } \\
\text { *Temel Bilimler }\end{array}$ & $\begin{array}{l}\text { *Genel Müzikoloji } \\
\text { *Genel Müzikoloji- } \\
\text { Müzik Teknolojileri } \\
\text { *Müzik Teorisi } \\
\text { *Müzikoloji } \\
\text { *Müzikoloji Müzik Teorisi } \\
\text { Etnomüzikoloji ve Folklor }\end{array}$ \\
\hline
\end{tabular}




\begin{tabular}{|l|l|l|l|}
\hline $\begin{array}{l}\text { KONSERVATUVAR } \\
\text { ADI }\end{array}$ & BÖLÜM ADI & ANASANAT DALI ADI & ANABíLíM DALI ADI \\
\hline \multirow{5}{*}{} & & *Teori -Kompozisyon & \\
& *THM/ TSM & \\
& *Tiyatro & \\
& *Tiyatro-Oyunculuk & \\
& *Türk Halk Müziği & \\
& *Türk Halk Oyunları & \\
& *Türk Sanat Müziği & \\
& *Üfleme ve Vurma Çalgılar & \\
& *Üfleme ve Vurmalı Çalgılar & \\
& *Üflemeli Çalgılar & \\
& *Üflemeli Çalgılar ve Vurmalı & \\
Çalgilar & *Üflemeli ve Vurma Çalgılar & \\
& *Üflemeli ve Vurmalı Çalgılar & \\
& *Üflemeli ve Vurmalı & \\
& Enstrümanlar & \\
& *Yaylı Çalgılar & \\
& *Yaylı Çalgılar Yapımı & \\
& *Yaylı Enstrümanlar & \\
& *Yaylı Sazlar & \\
& *Vurma Sazlar & \\
&
\end{tabular}

Yine bu yapılanmalar dikkatlice incelendiğinde eğitiminin toplumsal temellerinin göz ardı edildiği anlaşılmaktadır. Örneğin eğitimin işlevleri olduğu gibi konservatuvar eğitimin de işlevleri olmalıdır. Bu işlevler açık ve gizli olabilir. Konservatuvar eğitiminde de bireyin toplumsallaşması yanında ekonomik ve kültürel işlevler düşünülmelidir.

İçinde yaşanılan toplumsal yapı, tabakalar, sınıflar, toplumsal hareketlilikler düşünülerek konservatuvar eğitimi planlanmalı ve programlanmalıdır. Toplumsal değişim ve dönüşümlerde konservatuvar eğitimini etkiler. Oysa yukarıdaki tablo incelendiğinde ve konservatuvarların kendilerini tanıtırken kullandıkları terminoloji üzerinde özel bir inceleme yapıldığında bu ve benzeri bir çok konunun düşünülmediği belirlenecektir. 


\section{Konservatuvarların Paydaş Kurumlarla Olan İlişsileri ve Önemi}

Hükümetler, Kültür Bakanlığı, Milli Eğitim Bakanlığı başta olmak üzere bakanlıklar, TRT, genel müzik eğitimi veren kurumlar, amatör müzik eğitimi veren kurumlar, Belediyeler, dernek ve vakıflar, özel ve serbest çalışanlar, basın yayın organları akla ilk gelen paydaş kurumlar arasında. Her paydaşın kendine göre beklentileri var. Konservatuvarların eğitim felsefelerinde bu ve benzeri paydaşların beklentilerinin de iyi araştırılması, konservatuvar amaçlarına yön çizecektir.

\section{YÖK Lisans Programı Açma Ölçütleri ve Konservatuarların Durumu}

YÖK Lisans programı açılması için gerekli ölçütler ve bașvuru formatı dikkatlice incelendiğinde; maddeler halinde sıralanan belgelerin eksiksiz doldurulması istenmektedir.

Altıncı maddede; Programla ilgili yurtiçi ve yurtdışı örnekleri ayrı ayrı belirtiniz (Yurtdlşından en az 3 örnek). Programın Türkiye'de ve dünyadaki uygulamalar ile ilgili ayrintıl bilgi veriniz. Önerilen programin bu programlarla olan benzerliklerini ve farklılıkların açıklayınız.denilmektedir. Ülkemizde bu kadar farklı yapılanmaların olduğu bir durumda; dosyayı hazırlayanların benzerlik ve farklılıklarda ne dedikleri gerçekten merak konusudur.

Yedinci maddede ise; önerilen program, halen aynı bölüm ve/veya fakülte içerisinde yürütülmekte olan diğer programlarla işbirliği içerisinde olacak midır? Cevap evet ise, işbirliğinin ne şekilde gerçekleşeceğini somut olarak açıklayınız." Denilmiştir. Aynı çatı altında eğitim veren farklı müzik türleri vardır. $\mathrm{Bu}$ yapılanmaların olmasına yönelik ne tür açıklamalar yapılmıştır?

Sekizinci maddede ise;"önerilen programin, mevcut lisans programlarını zayıflatmadan nasıl yürütüleceğini somut olarak açıklanması" istenmektedir. TSM bölümü olan bir kurumda birden THM bölümü de açılabilmekte, hatta bölümlerden Anasanat dalları da çıkarılmaktadır. Sonrasında ise eğitimci sıkıntısı ile karşılaşılmaktadır. Ders yükleri çoğalan eğitimciler ise icra-üretim-sergileme-akademik gelişimlerinde ödün vermek durumuyla karşı karşıya kalmaktadırlar.

Onbirinci maddede ise Programdan mezun olanların hangi unvanı alacă̆ı öngörülmektedir? Sorusuna cevap verilmesi istenmektedir. YÖK mevzuatına göre konservatuvarların tanımı bellidir. Bununla birlikte ek1'deki tablo incelendiğinde öğrenciler kendilerini nas1 tanımlayacaklardır? 
Onikinci maddede; Programdan mezun olacaklarin nerelerde istihdam edilebilecekleri, piyasanın bu mezunlara olan talebi hakkında bilgi veriniz ve meslek elemanı tanım modelindeki değişimler açısından ilişkisi var mı? Açıklayınız denilmektedir. Bugün TRT, Kültür Bakanlığı ve özel sektörün sanata ve müziğe bakış açısı bellidir. Açılan kadrolar ortadır. Yapılan araştırmalarda lisanstan itibaren eğitime başlayan konservatuvarlardaki öğrencilerin büyük bir çoğunluğu "öğretmen” olmak istemektedirler. (AKÜ Devlet konservatuvarında 2009 yılında öğrenciler üzerinde yapılan bir anket çalışmasında \%92 öğrenci öğretmen olma istediğini belirtmişlerdir). Kurumlar bu ve benzeri durumlar karşısında yeni ve farklı stratejiler geliştirmekte midirler?

Tüm maddeler dikkatlice incelendiğinde konservatuvar yapılanmalarının neden bu kadar farklı olduğu sorusu aklımıza gelmektedir. Aynı zamanda; bu kadar net ve "somut" bilgi ve belgelerin istendiği ölçütlerin, bu ölçütleri yerine getirecek kurumda çalışan bireyin kendi bilgi birikimine göre hazırlandığı düşüncesini de beraberinde getirmektedir.

Akademik alt yapıda istenen ölçütlerde ise; önerilen programda ders verecek öğretim elemanlarının bilgileri, öğretim elemanlarının özgeçmişleri, Programın yürütülebilmesi için araştırma görevlisine ve yardımcı personele (uzman, teknisyen, v.b.) gerek varsa, bunların sayısı ve yeterliliği hakkında bilgi verilmesi istenmektedir.

Bugün bir bölüme öğrenci alabilmek için en az üç öğretim üyesi, bir Anasanat dalına öğrenci alabilmek içinse en az 1 öğretim üyesine ihtiyaç duyulmaktadır. Konservatuvarların öğretim üyesi sayıları dikkatlice incelendiğinde ve gerek yukarıda belirtilen ve gerekse yazışmalarla bildirilen ölçütlere göre hareket edildiğinde bir çok konservatuvarın öğrenci alamaması durumu ile karşılaşacağı bilinmektedir. Bir konservatuvar açılırken başka konservatuvarlardaki öğretim üyelerinin özgeçmişleri kullanılmaktadır. Fiziki Altyapıda istenen ölçütler dikkatlice incelendiğinde ve ülkemizdeki konservatuvarların fiziki imkânları düşünüldüğünde durumun hiç te iç açıcı olmadığı hemen görülecektir.

\section{Araştırmanın Yöntemi}

Araştırma; müzik sosyolojine yönelik bir düşünce temelinde yapılandırılmış, olgusal, karşılaştırmalı, geliştirmeci ve kuramsal sorular hazırlanmış ve cevapları bulunmaya çalışılmıştır. Giddens olgusal soruyu, ne oldu?, karşılaştırma sorusunu; bu her yerde oldu mu?, geliştirme sorusunu, bu zaman içinde tekrarlandı mi, kuramsal soruyu ise bu olgunun altinda yatan nedir? Sorularıyla açıklar.(2008;112) 
Araştırma için hazırlanan yapılandırılmış görüşme formunda;

Olgusal soruda ve cevabında; konservatuvar yapılanmalarının ne olduğu,

Karşılaştırma sorularında; konservatuvar yapılanmalarındaki farklılıklar her yeni kurumda olup olmadığ 1 ,

Geliştirme sorularında; konservatuvar yapılanmalarındaki farklılıklar zaman içinde tekrarlanıp tekrarlanmadığ 1

Kuramsal sorularda; konservatuvar yapılanmalarındaki farklılıkların altında yatan nedenlerin neler olduğu belirlenmeye çalış1 lmıştır.

$\mathrm{Bu}$ amaç doğrultusunda araştırma sürecinde şu esaslar gerçekleştirilmiştir.

Konuyla ilgili bilgi, belgeler ve ilgili araştırmalar taranmış,

Kaynaklar belirlenmiş,

Araştırmaya ilişkin verilerin elde edilebilmesi için lisans düzeyinde mesleki müzik eğitimi veren eğitimcilere uygulanmak üzere yapılandırılmış görüşme formu geliştirilmiş,

Araştırmaya gönüllü olarak katılan eğitimcilere yapılandırılmış görüşme formu uygulanmış,

Elde edilen veriler nitel çözümleme tekniklerine uygun olarak yazılı ortama aktarılmış, çözümlenmiş ve yorumlanmıştır.

Çalışmaya gönüllü olarak; Devlet konservatuvarı mezunu14, Devlet Türk musikisi konservatuvarı mezunu 7, Eğitim Fakültesi mezunu 6, Türk Müziği Devlet konservatuvarı 4 eğitimci katılmıştır.

\section{Bulgular ve Yorum}

$\mathrm{Bu}$ bölümde yapılandırılmış görüşme formunda yer alan düşüncelere eğitimcilerin verdikleri cevaplara yer verilmiştir. Konservatuvar adları, bölüm, anasanat dalı ve sanat dalı yapılanmalarına yönelik elde edilen veriler analiz edilmiş ve yorumlanmıştır. Keman sanatçısı ve akademisyen Cihat Aşkın'la yapılan görüşme ise ayrıca ele alınmıştır. Birbiriyle örtüşen cevaplar tekrar edilmemiștir.

Katılımc1lar; konservatuvar-konservatuar, musiki-müzik, Devlet TürkTürk Müziği Devlet gibi farklı adlandırmalar yerine tek bir adlandırma da karar kılınmalıdır düşüncesine katılmaktadırlar.

Katılımcılar; aynı eğitimi verdiği halde farklı "bölüm" adlandırmalarına gerek olmadığını, ortak bir adlandırmadan yana olduklarını belirtmişlerdir. Türk müziği eğitiminin Türk Halk müziği ve Türk sanat müziği olarak ayrılmaması gerektiği, Müzik bölümü altında tür ayırt etmeksizin çalg1 eğitiminin verilebileceği, her üniversite de aynı yapılanmanın tercih edilmesi 
gerektiği, müzik ve sahne sanatları fakültesi olarak yapılanmaların olabileceği diğer düşünceler olarak karşımıza çıkmakta.

Katılımcılar; aynı işi yapan ama farklı adlandırmalar içindeki Anasanat dalı yapılanmalarındaki durumunda eğitim öğretim birliğini etkilediğini, bu kargaşa durumundan çıkılarak, eğitim ve öğretimde birlik sağlanması gerektiğini düşünmektedirler.

Katılımcıların; aynı adla yapılanan bölüm ve anasanat dalı adlandırmalarının konservatuvar eğitiminde karmaşıklığa yol açtığını, özellikle yurt dişı akretide olmada engel teşkil ettiğini, kurumlar arası öğrenci değişimlerinde sorun yaşandığını düşünmektedirler. Temel bilimler adının doğru olmadığı, Türk müziğinin bir bütün olarak ele alınması gerektiği gibi önemli tespitlerde bulunmuşlardır.

Katılımcılar; icra ile ilgili birimlerin Anasanat dalı; teori ve araştırma ile ilgili birimlerin ise anabilim dalı olarak adlandırılması gerektiğini düşünmektedirler. Müzikoloji’nin bölüm veya anabilim dalı olarak adlandırılmasını önermektedirler.

Katılımcılar; kompozisyon eğitiminin Anasanat dalı içerisinde verilmesi gerektiğini düşünmektedirler. Bir önceki, soruya verilen cevaplarla bir karşıtlık oluşsa da ağırlıklı olarak bu görüş öne sürülmüştür.

Katılımcılar çalg1 yapım eğitiminin; bölüm yapılanması ile verilebileceğini düşünmektedirler. Bir katılımcı, "Çalg1 yapım Anasanat dalı olmalı. Çünkü çalgı yapım eğitiminin verildiği bir sanat dalıdır" görüşünü belirtmiştir.

Katılımcılar; sahne sanatları eğitiminin bölüm yapılanması altında verilmesi gerektiğini düşünmektedirler.

Katılımcıların "Türk müziği eğitimine" yönelik adlandırmalara ilişkin görüsslerinin keskin bir şekilde ikiye ayrıldığı belirlenmiştir. Bir tarafta Türk müziğinin bir bütün olduğu görüşü savunulurken, diğer tarafta bölümlerin ayrı ayrı yapılanması gerektiği savunulmuştur.

Katılımcılar; çekinceler olmakla birlikte, ağırlıklı olarak konservatuvarlarda Türk ve (Batı) Müzik Bölümleri'nin aynı çatı altında eğitim verebileceğini düşünmektedirler.

Katılımcılara göre geleceğin konservatuvar yapılanmaları:

Birbirleriyle örtüşen yorumlara yer verilmemiștir.

"Sahne Sanatları adı altında bir konservatuvar modeli olmalıdır"

"Kurumun ad konservatuvar olmall"

"Aynı çatı altında tüm müzik türleri eğitim verebilir. Bununla birlikte avantajlart; insanların birbirinden bir şeyler öğrenmesi, paylaşmast. 
Dezavantajları; olumsuz etkilenme, özellikle batı müziği ögrrencilerinin Türk müziği ögrencilerinde etkilenmesi”

"Üniversitelerden bă̆ımsız bir sanat ĕ̆itimi"

"Lise eğitimi olmalıdır"

"Özellikle medya ve iletişim araçlarının müziği en yaygın biçimde kullandı̆̆ yüzyılımızda geleneksel müzik yapılarımızın korunarak ve kullanilarak yeni çağdaş ve uygar müzik kültürümüzün dünya sanat standartlarına ulaşabileceği eğitimin verildiği bir yapılanma olmalıdır."

"Ney talebesinin Loillet'in Obua sonatlarını dinlediği, Bach Süitlerine çalışan çello ögrencisinin Tanburi Cemil Bey'in viyolonsel taksimlerinden de faydalandı̆̆l, halk müziği ses ögrencisinin Schubert'inDerLeierman'ını dinleyip kendinden geçtiği Şan eğitimi alan batı müziği öğrencisinin Münir Nurettin Selçuk'un tekniğini de dinlediği, viyolacının Dede Efendi'ye hayran kaldı̆̆ı ögrrencilerin aynı çatı altında, ayrımsız, ötekisiz, aklı selim, dedikodudan uzak, çalışkan, üretken, sergileyen, destekleyen ve destek gören bir durumda olmalarını sağlayacak bir model" "

"Gelecekte Konservatuarlar yerel, ulusal ve evrensel değerleri benimseyen ve bütünlükçü bir bakış açısıyla bilim ve sanat üreten kurumlar olmalidirlar"

"Müzik okulları ilköğretimden öğrenciyi almalı. Ayrım yapmadan genel müzik eğitimi verilmeli. Liseye gelindiği zaman sanatçı (yorumcu), eğitimci, öğretmen vb ayrılmalı"

"Küçük yaşlardan başlayan, üniversitelerden bağımsız bir model uygulanmal1."

"Her müziği bilen akademisyenler olmalı."

Araştırmaya ilişkin keman eğitimcisi Cihat Aşkın'la söyleşi:

Türkmen: Konservatuvar adlandırmalarına ilişkin görüşleriniz neler?

Aşkın: İsimlerin çeşitli olması yerine eğitim de birlik ilkesi kanaatimce daha doğru olur. Hele hele kültürel bazda eğitimin doğu-batı diye ayrılması doğru değildir.

Türkmen: Konservatuvarlardaki, "Bölüm” adlandırmalarına yönelik düşünceleriniz neler?

Aşkın: $\mathrm{Bu}$ konuda kültürel kavram karmaşasının olmaması için terimlerde standardizasyona gidilebilir.

Türkmen: Konservatuvarlarda aynı işi yapan ama farklı adlandırmalar içindeki Anasanat dalları adlandırılmıştır. Bu durum eğitim öğretim birliğini etkilemektedir. "Bu kaos durumundan çıkılmalı ve eğitim ve öğretimde birlik sağlanmalıdır” düşüncesine katılır mısınız?

Aşkın: Katılırım. 
Türkmen:Aynı adla yapılanan Bölüm ve Anasanat Dalı adlandırmalarına yönelik düşünceniz nedir?

Aşkın:Standardizasyona gidilmelidir.

Türkmen: Anabilim- Anasanat Dalı kavramları nasıl kullanılmalıdır?

Așkın: İcra ile ilgili olanlar sanat dalı, teori ile ilgili olanlar bilim dalıdır.

Türkmen: "Kompozisyon Bölümü, Kompozisyon Anasanat hangisi tercih edilmelidir?

Aşkın: Kompozisyon sanat alanı olmalıdır

Türkmen: Çalgı Yapım Bölümü, Çalg1 Yapım Anabilim Dalı adlandırmalarından hangisi tercih edilmelidir?

Aşkın: Şekil açısından fark etmez

Türkmen: Türk müziği eğitiminin ayrıştırılması düşüncesi ve uygulamasina nasil bakıyorsunuz?

Aşkın: Birleştirilmesinden yanayım

Türkmen: Konservatuvarlar Türk ve Batı müziği olarak ayrılmalı mı?

Așkın: Aynı çatı altında birleştirilmelidir.

\section{Sonuçlar ve Tartışma}

Konservatuvarlar ülke kültürünün gelişiminde ve değişiminde önemli bir etkendir. Yapı taşıdır.

Yerel ve evrensel kültüre ait müzik eğitimi ayrılmamalıdır.Yerel kültürün geliştirilmesi, gelecek kuşaklara aktarılması, korunması, evrensel kültürün tanıtılması, paylaşılması sürecinde konservatuvarlar önemli roller üstlenirler.

$\mathrm{Bu}$ kurumların yapılanmalarında, sorunlarının çözümünde kişi ve kurumlar etkin ama sabırl, planlı ve dirayetli kararlar alınmalıdır.

Konservatuvarların sanatsal ve eğitimsel seviyeleri, kendi içlerinde ortak bir yapılanma sayesinde daha da güçlenecektir. Hedeflerin gerçekleşmesi daha kolay olacaktır. Bireyler (aile, öğrenci, yetkili kişi vb) karşılarında tek renk ama güçlü bir renk görecektir.

$\mathrm{Bu}$ aynı zamanda konservatuvar çalışanlarının ve eğitimcilerinin de motivasyonlarının artmasına yardımcı olacaktır.

Konservatuvar mezunlarının istihdam edilebilmelerinde de yapılanma ortaklığının faydaları görülecektir. Mezun tanımlamaları netleşecektir.

Program adlarındaki birliktelikler, zaman içerisinde program içeriklerinde de ortaklıklara vesile olacak, o programın çağın getirilerine uygun gelişim ve değişimlerde katkı sağlayacaktır. 
Konservatuvar yapılanmalarındaki ortaklıklar ilgili kurum ve kuruluşlarında ilgisini çekecek, yeni ve farklı iş imkanlarının doğmasına, eşgüdüm sağlanmasına yol açacaktır.

Konservatuvarlarda müzik eğitimi/pedagojisi bölümlerinin olmas1, konservatuvar eğitiminin profesyonel, amatör ve genel müzik eğitimiyle de ilgilenebilmesine vesile olacaktır.

Üniversiteler arası kurul sanat konseyi daha etkin çalışmalı ve net kararlar almalıdır.

Konservatuvarların yurt dışı ilişkileri, Bologna süreci vb alanlarda da çalışmalar yapmalıdır.

\section{Kaynakça}

ABELES, H.F.,Hoffer, C.F., Klotman, R.H., (1994), Foundations of Music Education, An Imprint of Macmillan Publishing Company, New York.

GIDDENS, A. (2008), Sosyoloji, İstanbul: Kırmızı Yayınları.

GÜNAY, E. (2006), Müzik Sosyolojisi, İstanbul: Bağlam Yayıncılık.

USMANBAŞ, İ. (1988), Sanat ve Müzik Sorunlarına Genel Bakışlar, Birinci Müzik Kongresi-Bildiriler Kültür ve Turizm Bakanlığı Güzel Sanatlar Genel Müdürlügü, Ankara.

ÜNALP, A. (2013), “Ülkemizde Oda Müziği Kültürünün Neresindeyiz?", İstanbul: Andante Dergisi, Mart 2013, sayı:78.

SAY, A. (2007), Müzik Yazıları, Ankara: Müzik Ansiklopedisi Yayınları.

http://hanimdemirbas.com.tr/pedagoji.php (04.02.2013, saat 12.00)

http://www.sosyalpedagog.com/sosyal-pedagoji-nedir (11.03.2013)

https://www.yok.gov.tr/content/view/507/210/(31.01.2013)

Cihat Aşkın'la görüşme: 03 Mart 2013-İstanbul MİAM 